\title{
Pemberdayaan Balai Perempuan Gumi Asah dalam Pengolahan Kacang Tanah di Desa Giri Tembesi
}

\author{
Animah*, D. Tialurra Dellanabila, Widia Astuti, Aditya Bayu Suryantara \\ Jurusan Akuntansi Fakultas Ekonomi dan Bisnis Universitas Mataram
}

Kata Kunci: Kacang Tanah, Produksi, Pemberdayaan

\begin{abstract}
Abstrak: Kacang tanah merupakan komoditas utama di desa Giri Tembesi Kecamatan Gerung Kabupaten Lombok Barat Nusa Tenggara Barat. Selama ini, para petani menjual kacang dalam bentuk yang sudah dikupas dan belum dikupas, sehingga pendapatan yang diterima relative sedikit. Oleh karena itu memerlukan bantuan untuk meningkatkan aktivitas ekonomi para petani kacang tersebut. Kegiatan pengabdian ini bertujuan untuk meningkatkan pemahaman penciptaan nilai tambah produk kacang pada ibu-ibu petani kacang yang tergabung dalam Balai Perempuan Gumi Asah, dengan cara memberikan pengetahuan mengenai eknik produksi pengolahan kacang serta membuat perhitungan biaya produksi dan teknik pemasaran yang tepat agar menghasilkan pendapatan yang optimal. Metode yang digunakan adalah dengan mengadakan pelatihan kewirausahaan, meliputi ceramah, tanya jawab, demonstrasi, latihan atau praktek, display. Hasil pelatihan menunjukkan bahwa ibu-ibu balai perempuan Gumi Asah mampu mengolah kacang tanah menjadi kacang telur, peyek, dan sambal pecel. Selain itu mereka juga memahami teknik produksi pengolahan kacang tanah dengan membuat perhitungan biaya produksi serta Teknik pemasaran yang tepat untuk mengoptimalkan pendapatan melalui media social sebagai media penjualan dan promosi.
\end{abstract}

\section{Korespondensi:animah@unram.ac.id}

\section{PENDAHULUAN}

Kecamatan gerung merupakan salah satu dari sepuluh kecamatan yang terdapat di kabupaten Lombok barat. Kecamatan gerung memiliki tiga kelurahan dan 11 desa. Giri tembesi merupakan salah satu desa yang ada di kecamatan gerung yang merupakan desa pemekarandengan luas wilayah $11,99 \mathrm{~km}^{2}$. Desa giri tembesi memiliki 5 dusun yaitu dusun lilin, dusun teluk gedang, dusun gumese utara, dusun gumese selatan, dusun gumese tengah. dengan potensi pertanian, perkebunan dan peternakan.

Dusun gumese selatan terletak disebelah selatan dan melewati jalan berbukit dengan rata-rata penduduk dusun menjadi petani. Hasil pertanian yang paling banyak selain padi adalah kacang tanah. Kacang tanah selama ini hanya dijual oleh petani dalam bentuk kacang yang sudah dikupas bahkan ada juga yang menjual tanpa dikupas lebih lanjut karena berharap memperoleh uang secara cepat. Oleh karena itu masih membutuhkan bantuan untuk meningkatkan aktivitas ekonominya. Dengan melakukan usaha kreativitas dan inovasi pada pengolahan kacang sebenarnya dapat dimanfaatkan menjadi peluang usaha mikro, kecil dan menengah terutama bagi ibu-ibu yang tergabung dalam kelompok Balai Perempuan (BP) gumi asah.

Kelompok balai perempuan gumi asah selama ini hanya mengadakan kegiatan mengolah olahan pisang dari kebun dalam bentuk produk sale pisang yang pelaksanaannya dua kali dalam seminggu dengan keuntungan sebesar Rp 30,000 per kegiatan dibagi 30 orang, sehingga dalam satu bulan per orang hanya menghasilkan Rp 8.000. Kelompok BP 
gumi asah ini tidak melaksanakan kegiatan pengolahan produk lainnya karena keterbatasan pengetahuan dalam pengolahan produk pertanian, padahal keinginan untuk membuat produk selain sale pisang ada, hanya yang dibutuhkan adalah orang yang mampu memotivasi dan memberikan keterampilan dalam pengolahan hasil pertanian.

Pilihan dalam usulan program pengabdian di dusun gumese selatan dengan maksud untuk meningkatkan pemahaman dan keterampilan masyarakat desa terutama pada balai perempuan gumi asah sehingga dapat menghasilkan produk bernilai ekonomi tinggi yang berdampak pada peningkatan pendapatan dan kesejahteraan masyarakat secara signifikan.

Berdasarkan permasalahan di atas, maka perlu adanya pemecahan dan solusi terhadap suatu usaha yang dapat meningkatkan penghasilan masyarakat dalam mengolah produk selain berbahan pisang yaitu kacang tanah menjadi produk yang bernilai tambah. Metode pelaksanaan pengabdian ini melalui tahap sosialisasi, dan pelatihan teknik pengolahan kacang menjadi produk yang bernilai tambah serta perhitungan biaya produksi untuk menentukan harga jual produk. Program pengabdian ini dilaksanakan secara sinergi bersama lembaga mitra yaitu BP gumi asah dengan cara sharing pengetahuan dan tenaga pendamping. Diharapkan dengan pola ini dapat meminimalisir permasalahan ekonomi masyarakat khususnya BP gumi asah yang ada di desa giri tembesi.

\section{METODE KEGIATAN}

Mitra kegiatan pengabdian ini adalah ibu-ibu yang tergabung dalam balai perempuan Gumi Asah. Berdasarkan hasil wawancara dengan ketua kelompoknya yang bernama ibu widi, terdapat beberapa permasalahan yang dihadapi oleh balai perempuan gumi asah antara lain:

1. Balai perempuan gumi asah hanya memiliki pegetahuan yang terbatas mengenai pengolahan hasil pertanian, padahal di dusun gumese ini memiliki potensi yang besar terkait dengan ketersediaan bahan baku terutama kacang tanah. Balai Perempuan gumi asah selama ini hanya mampu memproduksi pisang sale itupun seminggu dua kali karena ketersediaan bahan baku yang terbatas.

2. Kurangnya pengetahuan mengenai pengemasan hasil olahan pangan.

3. Kurangnya ketrampilan manajemen di dalam memasarkan produk berbasis teknologi informasi.

Berdasarkan permasalahan mitra, beberapa metode dapat dilakukan dengan memberikan solusi antara lain:

1. Penyuluhan berbagai produk olahan kacang dan manajemen keuangan di dalam produksinya

2. Pelatihan produksi olahan kacang

3. Pelatihan pemasaran produk kacang

\section{HASIL DAN PEMBAHASAN}

Adapun beberapa hasil yang dicapai dalam pelaksanaan kegiatan pengabdian ini adalah :

1. Penyuluhan produk olahan kacang dan perhitungan harga pokok produksi 
Penyuluhan ini ditujukan untuk ibu-ibu warga Desa Giri Tembesi. Khususnya yang tergabung dalam balai perempuan gumi asah, Kegiatan penyuluhan diawali dengan memperkenalkan pentingnya berwirausaha kepada ibu-ibu Desa Giri Tembesi. Selanjutnya diberikan materi mengenai aneka produk olahan dari kacang seperti kacang telur, sambal pecel dan peyek. Diharapkan dengan adanya penyuluhan ini ibu-ibu dapat memperoleh pengetahuan akan beragam jenis olahan dari kacang. Sehingga ibu-ibu dapat mempraktekkan ilmu yang telah diperoleh untuk dijadikan peluang usaha.

Penyuluhan ini tidak hanya mengenai produk olahan kacang melainkan juga perhitungan biaya produksi olahan kacang, dengan tujuan untuk mengajarkan masyarakat dalam mengatur kas, modal sampai pendapatan dengan tujuan agar produksi kacang ini dapat terus berjalan secara efisien dan terarah. Selain itu diberikan informasi bahwa untuk menjadi seorang pengusaha dibutuhkan perjuangan dan tidak langsung menikmati hasil yang melimpah. Anggapan ibu-ibu ketika mulai berwirausaha adalah langsung memperoleh hasil yang maksimal, sehingga banyak ibu-ibu yang tidak melanjutkan kegiatan wirausahanya dikarenakan hasil yang diperoleh hanya sedikit. Namun jika ditekuni tentunya usaha tersebut akan berkembang dan penghasilan yang diperoleh ibu-ibu akan lebih banyak lagi.

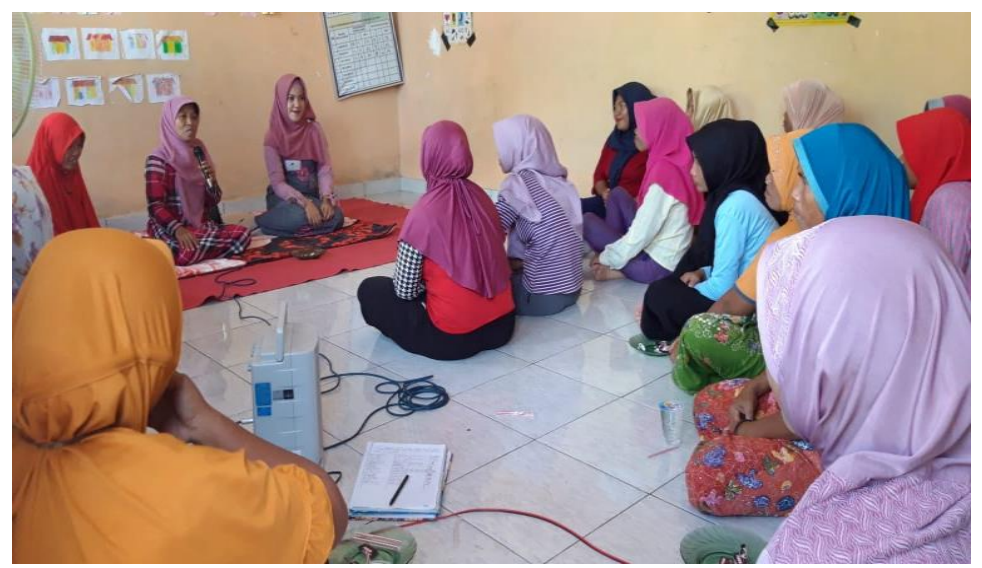

2. Pelatihan produksi olahan kacang

Pengolahan produk kacang dilakukan dalam beberapa tahap, mulai dari penyiapan alat dan bahan yang dibutuhkan untuk produksi, pembuatan produk hingga menjadi produk jadi. Produk kacang yang akan diolah yaitu kacang telur, sambal pecel dan peyek.

\section{Produksi Kacang Telur}

Kacang disangrai terlebih dahulu, sampai agak kuning, kemudian diangkat dan dihilangkan kulitnya. Siapkan bahan yang dihaluskan yaitu garam \& bawang putih, kemudian campur dengan gula halus dan telur, masukkan kacang kedalamnya. Siapkan tepung terigu dan tepung tapioca pada nampan yang berukuran besar lalu masukkan kacang yang sudah dilumuri adonan aduk sampai rata, kemudian goreng dengan api sedang sampai matang. Setelah agak dingin kemudian kacang dikemas dalam kemasan yang sudah disiapkan. 


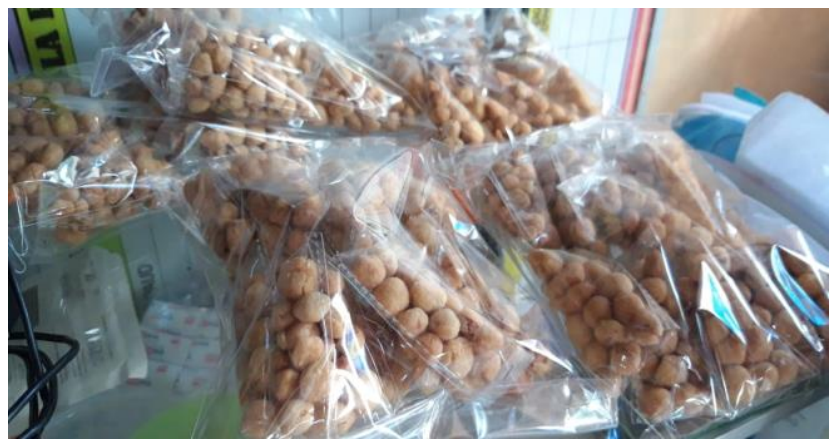

\section{Produksi Sambal Pecel}

Kacang tanah digoreng tersendiri, kemudian kencur, cabe rawit, cabe merah dan bawang putih digoreng bersamaan. Semua bahan kacang tanah, kencur, cabe rawit, cabe merah, daun jeruk, gula merah, bawang putih, garam dan asam jawa digiling. Setelah tercampur dikemas dalam kemasan yang sudah disiapkan sesuai dengan takaran.

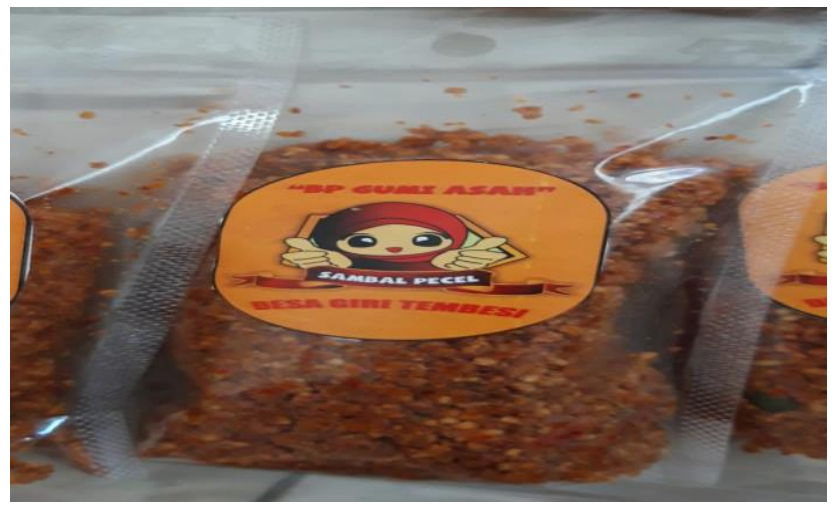

\section{Peyek Kacang Tanah}

Bahan yang dihaluskan kemiri, garam, bawang putih, ketumbar. Campur semua bahan yang dihaluskan dengan tepung beras, tepung tapioca, royco, santan dan telur. Masukkan kacang tanah dan daun jeruk ke dalam adonan, lalu tuang dalam cetakan yang sudah disipkan goreng dengan minyak panas sampai terlepas dari cetakan hingga matang. Kemudian angkat, setelah dingin masukkan dalam kemasan yang sudah disiapkan.

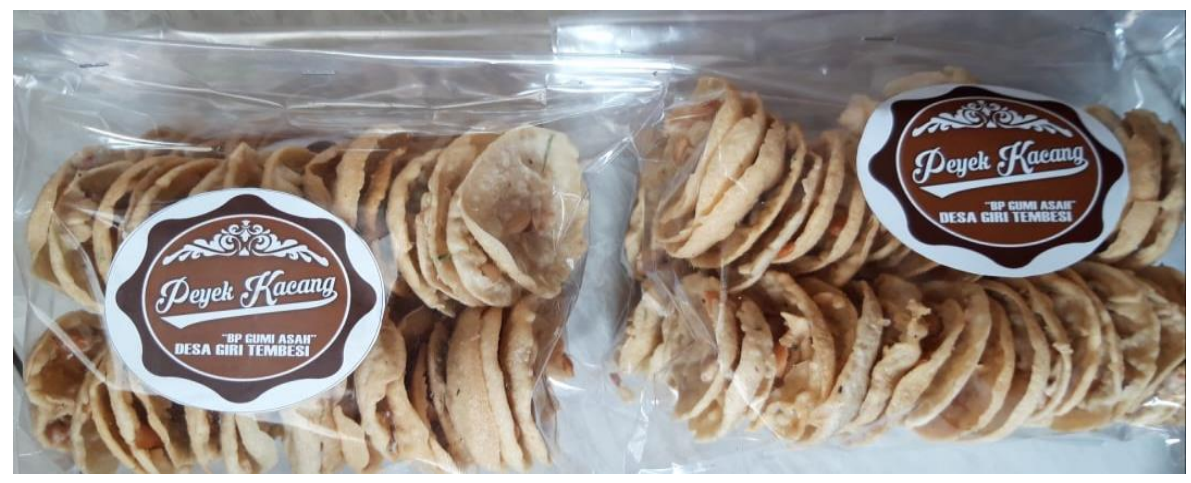


3. Pelatihan pemasaran

Pelatihan pemasaran dilaksanakan dengan terlebih dahulu melakukan kegiatan sosialisasi mengenai strategi pemasaran produk baik secara offline maupun online. Proses pemasaran secara ofline dengan cara ditawarkan kepada ibu-ibu yang menunggu putranya disekolah PAUD Guni Asah dan dengan cara menaruh produk di beberapa sekolah di lingkungan desa Giri tembesi terutama untuk produk kacang telur. Sedangkan produk peyek dan sambel pecel di coba dengan menjual secara online lewat Instagram dan facebook melalui pendampingan yang dilakukan oleh mahasiswa KKN yang ada di giri tembesi.

Berdasarkan metode penyuluhan dan pelatihan pengolahan kacang tanah ini balai perempuan gumi asah mampu membuat produk olahan dari kacang dan mampu menghitung biaya produksi serta memasarkan baik secara ofline maupun online.

\section{KESIMPULAN DAN SARAN}

Adapun simpulan yang diberikan dari kegiatan ini adalah

1. Balai perempuan gumi asah memahami cara membuat peyek kacang tanah, sambal pecel dan kacang telur.

2. Balai perempuan gumi asah mampu menghitung biaya produksi peyek kacang tanah, sambal pecel dan kacang telur

3. Balai perempuan gumi asah mampu memasarkan produk peyek kacang tanah, sambal pecel dan kacang telur baik secara offline maupun online

\section{DAFTAR PUSTAKA}

Anggraini, Renny: Maulina, Fera ; Vivi. 2019. Pemberdayaan Masyarakat Melalui Diversifikasi Produk Keladi dan Singkong. Jurnal Pengabdian dan Pemberdayaan Masyarakat Vol 3 No1 Maret 2019

Anonimus. 2017. Kabupaten Lombok Barat Dalam Angka. Pusat Statistik Kabupaten Lombok Barat

Blocher, Edward J, Kung H. Chen, Gary Cokins, dan Thomas W. Lin. 2007. Manajemen

Biaya Penekanan Strategis. Dialih bahasakan oleh David Wijaya. Jakarta:

Penerbit Salemba Empat

Hansen \& Mowen. 2004. Manajemen Biaya, Edisi Bahasa Indonesia. Buku Kedua. Jakarta: Salemba Empat

Hansen dan Mowen. 2009. Akuntansi Manajerial, Buku 1 Edisi 8. Jakarta: Salemba Empat.

Lathifah,Anthin;Ernawati,Brilliyan;Yuningrum,Heny.2015.Pemberdayaan Ekonomi Pekerjaan Rumah Tangga Melalui Pelatihan Kerajinan Payet Di Kelurahan Sumurbroto Kecamatan Banyumanik Semarang.Dimas Vol 15 No 1 Oktober 2015 
Marsigit, wuri.2010. Pengembangan Diversifikasi Produk Pangan Olahan Lokal

Bengkulu Untuk Menunjang Ketahanan Pangan Berkelanjutan.Agritecch Vol 30 No4 November 2010

Riyanto Bambang. 2001. Dasar-Dasar Pembelanjaan Perusahaan Edisi 4. Yogyakarta:

BPFE

Robbins, Stephen, 2006, "Perilaku Organisasi”, Prentice Hall, edisi kesepuluh

Zulchi,Try dan Puad, Husni.2017.Keragaman Morfologi dan Kandungan Protein Kacang tanah (Arachis hypogaea L).Bul Plasma Nutfah 23 (2).91-100 